TEME, г. XLII, бр. 4, октобар - децембар 2018, стр. 1107-1122

Оригинални научни рад

DOI: $10.22190 /$ TEME1804107B

Примљено: 12. 8. 2017.

Ревидирана верзија: 1. 7. 2018.

UDK 618.177-089.888.11(497.11)

Одобрено за штампу: 30. 9. 2018.

\title{
ATTITUDES OF INFERTILE WOMEN IN SERBIA TOWARDS THIRD-PARTY REPRODUCTION
}

\author{
Ana Bilinović Rajačicí ${ }^{*}$, Marija Zotović $^{2}$, \\ Marko Škorić ${ }^{1}$, Ksenija Kričković Pele ${ }^{3}$ \\ ${ }^{1}$ University of Novi Sad, Faculty of Philosophy, Department of Sociology, \\ Novi Sad, Serbia \\ ${ }^{2}$ University of Novi Sad, Faculty of Philosophy, Department of Psychology, \\ Novi Sad, Serbia \\ ${ }^{3}$ University of Novi Sad, Faculty of Medicine, Clinical Centre of Vojvodina, \\ Department of Gynaecology and Obstetrics, Novi Sad, Serbia \\ *ana.bilinovic@ff.uns.ac.rs
}

\begin{abstract}
Third-party reproduction refers to the use of gametes, embryos or gestation that have been provided by a third party to enable an infertile individual or couple to become parent(s). The social, legal, and ethical acceptability of third-party reproduction varies around the world. In Serbia, there is a noticeable lack of data on attitudes towards infertility treatments involving the use of donated gametes, as well as surrogacy arrangements, due to the fact that this practice is banned in this country. The aim of this paper is to examine the attitudes of infertile women in Serbia towards third-party reproduction, i.e. gamete donation and surrogate motherhood as potential parts of their own infertility treatments. The sample included 50 infertile women involved in the program of in vitro fertilization, which amounts to at least $10 \%$ of the total number of women who go through the program of state-funded in vitro fertilization in Novi Sad each year. The questionnaire, constructed for the purpose of the study, was administered. The participants expressed negative attitudes towards using third-party gamete donation and surrogacy in their own infertility treatments. The negative attitudes were most prevalent among participants with low- and medium-level education. The potential reasons for such attitudes are discussed.
\end{abstract}

Key words: infertility, Serbia, third-party reproduction, donated gametes, surrogacy. 


\title{
СТАВОВИ НЕПЛОДНИХ ЖЕНА У СРБИЈИ ПРЕМА КОЛАБОРАТИВНОЈ РЕПРОДУКЦИЈИ
}

\begin{abstract}
Апстракт
Колаборативна репродукција је термин који се односи на употребу гамета или ембриона, као и на гестацију коју обезбеђује трећа особа како би неплодна индивидуа или неплодни пар могли да постану родитељи. Друштвена, правна и етичка прихватљивост колаборативне репродукције разликује се у различитим деловима света. У Србији је очигледан недостатак података о ставовима према третманима неплодности путем употребе донираних гамета, као и путем сурогат материнства, услед забране ове праксе у држави. Циљ истраживања је испитивање ставова неплодних жена у Србији према колаборативној репродукцији, тј. донирању гамета и сурогат материнству као методама лечења неплодности. Узорак је укључивао 50 неплодних жена, које су укључене у процес in vitro оплодње, што чини минимум 10 \% од укупног броја жена које пролазе кроз програм финансиран од стране државе на клиници у Новом Саду. Испитанице су испуњавале упитник сачињен за потребе истраживања. Највећи број испитаница има негативне ставове према оплодњи путем донираних гамета и сурогат материнству као методама лечења неплодности. Негативни ставови најзаступљенији су код испитаница са нижим и средњим нивоом образовања. Могућа објашњења добијених резултата су дискутована.
\end{abstract}

Кључне речи: неплодност, Србија, асистирана репродукција, донирање гамета, сурогат материнство.

\section{INTRODUCTION}

From the vantage point of the Western medical discourse, infertility is defined as the inability to conceive or carry a pregnancy to term after twelve months or more of regular unprotected sexual intercourse with the intent of conceiving (van Balen \& Inhorn, 2002, p. 12; Greil, 2002, p. 101). It is typically regarded as a medical and social state in which the affected individuals are "located" somewhere between reproductive incapacity and capacity (Sandelowski \& de Lacey, 2002, p. 35). In response to the difficulties posed by infertility, immense strides have been made in the development and use of assisted reproductive technologies around the globe. The most contested assisted reproductive technologies are those that involve the use of third-party reproduction (Beeson, Darnovsky, \& Lippman, 2015), also known as "collaborative reproduction" (Robertson 1994, p. 119). The phrase refers to the use of gametes (egg/oocyte and sperm), embryos or gestation provided by a third party, allowing an infertile individual or couple (intended recipient) to become parent(s). Recently, it has also come to apply to maternal spindle transfer and pronuclear transfer, which are in vitro fertilization-based techniques for reducing maternally inherited pathogenic mutation of mitochondrial DNA 
in preimplanted embryos through its replacement with mitochondrial DNA from a healthy donor (Poulton \& Oakeshott, 2012, p. 10).

The need for donor sperm may arise in cases when a woman's partner is infertile due to biological incapacity (low sperm count), previous vasectomy, as well as when there is a risk of transmitting hereditary diseases to the offspring, or in the case when the man has an Rh factor or antibody incompatibility with his female partner (Jackson, 2001, p. 165). Single women and same-sex female partners wishing to get pregnant can also utilize sperm donation combined with assisted reproduction techniques. Donor sperm can be used in artificial ("alternative") insemination (AI) and in vitro fertilization procedure (IVF), if the female partner has a fertility problem as well. The practice itself was not very popular and accepted until the 1950s, when the introduction of sperm cryopreservation procedure expanded the potential use of artificial insemination. However, artificial insemination using donor sperm has retained highly controversial character. This is largely due to sperm donation being associated with masturbation, a woman's insemination with the sperm from a third party being treated as a form of adultery, as well as the belief that inseminating a married woman with donor sperm introduces "a false strain of blood" into the husband's family, making an AID child "illegitimate" (Corea, 2005). The creation of embryos through in vitro procedure (either with donor sperm or sperm from the partner/husband) also poses numerous legal and ethical dilemmas, the most persistent of which concerns the legal and moral status of human embryo.

The need for egg (oocyte) donation may arise in cases when the woman has declining ovarian function, poor oocyte quality or ovarian failure causing her to be infertile, as well as when the woman is a carrier of a severe genetic disorder which may pose a danger to the offspring (Jackson, 2001, 166). The first case of a child being conceived and born using a donated egg was documented in Australia in 1983, when a menopausal woman became pregnant with the help of a donated oocyte provided by a younger fertile woman (Beeson, Darnovsky, \& Lippman, 2015, p. 805). The "belated" use of this procedure in comparison to the practice of artificial insemination using donor sperm is the result of the fact that egg donation is a far more complicated procedure which requires the participants to be much more engaged in the process. In egg transfer, both the provider and the recipient need to go through a series of medical treatments. The donor receives hormone injections in order to induce ovulation, the effects of which may include Ovarian Hyperstimulation Syndrome (OHSS), as well as symptoms similar to those in menopause, such as hot flashes, insomnia and other unpleasant physiological changes (Ikemoto, 2009, 770; Krawiec, 2009, p. 65). The recipient in egg transfer also has to go through a hormonal treatment in order to synchronize her menstrual cycle with that of the provider, and she often has to receive additional hormone injections for a brief period of time after the egg 
transfer in order to improve the chances of a successful implantation of the egg into the uterine wall (Shanley, 2002, p. 265).

Surrogate motherhood is a gender-specific social arrangement in which a woman other than the "intended" mother gestates and gives birth to a child for the "intended" parents (commissioning couple or individual). There are two types of surrogate motherhood - genetic and gestational (McLachlan \& Swales, 2009, p. 92). In genetic surrogacy, the surrogate mother shares a genetic bond with the child she is carrying. She usually gets impregnated via artificial insemination by the male partner from the commissioning couple. In gestational surrogacy, the surrogate, also referred to as "gestational carrier" (Twine, 2011, p. 7), is implanted with an embryo created via in vitro fertilization and she shares no genetic bond with the child she bears. This type of surrogacy is suitable in cases when the intended mother has functional ovaries, but is unable to gestate an embryo, thus still having the possibility to genetically contribute in the creation of the child via in vitro fertilization (Anleu, 1992, p. 31). Alternatively, a woman other than the surrogate or the "intended" mother may donate ova or a man other than the "intended" father may donate sperm to be used in in vitro fertilization and the resulting embryo is placed into the womb of a surrogate.

Usually, a distinction is made between commercial surrogacy and altruistic surrogacy. Commercial surrogacy implies a payment being made to the surrogate mother for the service of gestation and birth of a child, while altruistic surrogacy is an arrangement which either includes no financial compensation for the surrogate mother, or a payment which only covers the expenses involved in carrying a pregnancy (Anleu, 1992, p. 37).

\section{THE TRANSFORMATION OF VALUE PATTERNS IN SERBIA \\ IN THE DOMAIN OF FAMILY, MARRIAGE AND PARENTHOOD: IMPLICATIONS FOR THIRD-PARTY REPRODUCTION}

Reproductive practices are greatly shaped by the sociocultural context of the society in which they exist. More specifically, the examination of the manners of application, legislation, and attitudes towards third-party reproduction requires the wider explanatory framework of structural and sociocultural characteristics of the given society (Bilinović, 2016). In the case of Serbia, this implies an analysis of this subject that would point to the structural and cultural order in this transitional country, with an emphasis on the transformation of family and partnership forms and relationships, as well as the transition of parenthood.

The results of numerous studies (Gavrilović \& StjepanovićZaharijevski, 2012; Zaharijevski, 2009; Blagojević, 2007; Milić, 2010; Manić, 2016) show that in transitional countries like Serbia, there is a conflict of values reflected in the simultaneous existence and preservation of traditional/patriarchal and modern/liberal values, which points to the 
parallel existence of pre-modernity, modernity, and post-modernity. This transformation/transition of value patterns is particularly conspicuous in the spheres of family, marriage/partnership, and parenthood. For instance, Milić (2001) points to three models of parenthood typical for contemporary Serbia: traditional form, symmetrical form, and rejection of parenthood, while Bobić (2003) identifies three types of consensual unions: traditional, transitional, and egalitarian.

According to the data provided in certain research on the subject of value transition in Serbia, family is the union that is given the greatest importance (Gavrilović \& Stjepanović-Zaharijevski, 2012). Marriage is predominantly viewed as an exclusive form of partnership, which is a "traditional value marker" (Gavrilović \& Stjepanović-Zaharijevski, 2012) that ignores the plurality of partner and family forms and relationships. Children are extremely highly valued as a factor for successful marriage, which points to existence of the traditional pattern. However, this can also be viewed within the framework of modern individualistic values, having in mind the results of various studies (Gavrilović \& StjepanovićZaharijevski, 2012; Manić 2016) that show that the majority of participants also believe that they (and people in general) should have the right to decide whether they want to have children. The value model in the sphere of parenthood reflects the preservation of the traditional model. Namely, an analysis of attitudes towards parenting reveals the belief that a man and a woman need to have children in order for their lives to be complete. Therefore, in the observed dimensions, the preservation of the traditional model is greatly confirmed, as well as the simultaneous existence of modern individualistic values. This further indicates the absence of stable value models (Gavrilović \& Stjepanović-Zaharijevski, 2012).

In the context of the transition of value patterns, it is interesting to point to the findings reported by Milic (2001), who analyzes the family value system on three levels. Namely, on the first level/the level of global society, at work is a family value system concerned with desirable definition of family form, composition, and function. On the second level/the level of families as concrete family groups, the group family system is nurtured, in the sense of the preservation of the stability of family as a group. On the third level/the individual level, there are family values that prescribe the desirable norms of conduct within family. In the circumstances of social turmoil and social changes, these three levels are often in discord, which may lead to certain changes on the group and individual levels, that is, the formulation of new values, while at the same time, the traditional family value system is preserved on the global level, both in terms of family form and functions. The reverse is also possible for example, the liberalization of gender relations on the global level with the simultaneous existence and preservation of the traditional, patriarchal value system between men and women on the family level. 
It is particularly interesting to point to another form of discord between value patterns in Serbia, reflected in the existence of two conflicting discourses: the discourse of reproductive rights and liberties (self-determination in terms of reproductive behavior) and the pro-natalist discourse in service of the ideology of nationalism (Manić 2012; Drezgić 2008, 2010).

\section{NATIONAL PROGRAM OF TREATING INFERTILITY VIA BIOMEDICALLY ASSISTED FERTILIZATION IN SERBIA}

The practice of assisted reproduction in Serbia was introduced during the late 1980s. Regulations regarding state-funded assisted reproduction treatments were introduced in 2006, when the Serbian Ministry of Health started a program of offering free IVF cycles to 1000 couples (Kričković Pele, 2014). Since 2006, state funding of assisted conception has been regulated by the Strategy for Increasing Birth Rate and the Act on Treating Infertility via Biomedically Assisted Fertilization (Official Gazette RS, 2009b), implemented by the Ministry of Health. The Act on Treating Infertility via Biomedically Assisted Fertilization states that assisted reproduction treatments should be available to men and women of legal, working age, who are married or in a stable relationship. Under special circumstances and for particularly justified reasons, single women can also have the right of access to assisted reproduction treatments, given that they meet other requirements prescribed by the law.

More detailed criteria for applying for state aid within the approved programs of assisted conception at certain clinics are determined by a special committee appointed by the Ministry of Health (Kričković Pele, 2014).

According to the latest $\left(15^{\text {th }}\right)$ report of the European IVF-Monitoring Consortium (EIM) for the European Society of Human Reproduction and Embryology (ESHRE), Serbia is at the bottom of the list of European countries when it comes to the number of completed IVF cycles (Kupka et al., 2011). Regarding the number of embryos implanted in the course of IVF cycles, the data show that there are a large number of cases of transferring three embryos in a single IVF cycle (58\%), as well as transferring two embryos per cycle (25.6\%) (Kupka et al., 2011). Such practice leads to an increase in the number of births of twins and triplets, making Serbia the second European country, after Moldavia, with the highest triplet delivery rate (Kupka et al., 2011). This is the result of a generally low and limited state funding of infertility treatments, which makes multiple pregnancies more "economical".

The report of the European IVF-Monitoring Consortium (EIM) for the European Society of Human Reproduction and Embryology (ESHRE) includes no information on the use of donated gametes for the purpose of fertilization in Serbia. Relatively recently (in 2013), Serbia has introduced a 
unique registry of gamete donors (Official Gazette RS, 2009a). The use of donated gametes is regulated by the expert advisory committee on the use of donated gametes in the process of biomedically assisted fertilization.

Surrogacy arrangements are not allowed in Serbia. The introduction of exclusively noncommercial form of surrogacy is included in the draft of the Civil Code which should be adopted by the end of 2017.

\section{PURPOSE OF THE STUDY}

Taking into account the lack of clinical data on infertility treatments involving the use of donated gametes and the prohibition of surrogate motherhood in Serbia, we examine the attitudes of women with a biomedical barrier to fertility towards third-party reproduction, i.e. gamete donation and surrogate motherhood as potential parts of their own infertility treatments.

The stated attitudes regarding these topics were compared by taking into consideration the different levels of education of the participants.

\section{METHOD}

\section{The Sample}

The sample included 50 infertile women involved in the program of in vitro fertilization, which amounts to at least $10 \%$ of the total number of women who go through the program of state-funded in vitro fertilization in Novi Sad each year. The participants were over the age of 18, married or living with a partner, with no live born children and with a history of being treated for infertility. At the time when the research was conducted, nearly half of the participants (46\%) were going through their first IVF treatment, while the other half comprised participants who have already gone through one (24\%), two (14\%), three (12\%) or four IVF cycles $(4 \%)$.

For comparison purposes, the subjects were divided into two groups. The first group $(\mathrm{N}=21)$ comprised participants with low- (primary school) and medium-level education (secondary school). The second group (N=29) included participants with high level of education, that is, women with a bachelor's or master's degree or a $\mathrm{PhD}$.

\section{Procedure}

The research was conducted in the period from November 2013 to March 2014, at the Obstetrics and Gynecology Clinic of the Clinical Center of Vojvodina in Novi Sad (Serbia). The subjects were asked to fill out a form during the hospitalization due to oocyte retrieval and on the day of embryo transfer and they were previously informed about the goals of the research, familiarized with the structure of the questionnaire and informed that the obtained data would be used exclusively for scientific 
purposes. Along with each questionnaire, the participants received two documents - Information for the participant and Informed consent - in accordance with the guidelines issued by the Ethical Board of the Clinical Center of Vojvodina. Four patients refused to take part in the research.

\section{Instrument}

The questionnaire, designed for the purpose of the study, was used for collecting data. The attitudes of the participants towards third - party reproduction, i.e. gamete donation and surrogate motherhood as potential parts of their own infertility treatments were obtained by asking them whether they would agree to use the aforementioned reproduction-aiding techniques. The structure of the questionnaire allowed the participants to answer by choosing between three options: yes, no and undecided.

\section{Data Analysis}

Data analysis, using SPSS, included the use of descriptive statistics to calculate frequencies and percents, and to compare the responses between the groups of respondents with different levels of education.

\section{RESULTS}

Table 1 shows the frequency and percentage of the answers the participants gave when asked about their attitudes towards using donated gametes and surrogacy in their own infertility treatments.

Table 1 Attitudes towards the use of the aforementioned reproduction-aiding techniques

\begin{tabular}{lccc}
\hline In treating infertility, would you agree to: & Yes & No & Undecided \\
\hline using donated eggs & $8(16.0 \%)$ & $22(\mathbf{4 4 . 0 \%})$ & $20(40.0 \%)$ \\
using donated sperm & $2(4.0 \%)$ & $32(\mathbf{6 4 . 0 \%})$ & $16(32.0 \%)$ \\
surrogacy arrangement & $7(14.6 \%)$ & $28(\mathbf{5 8 . 3 \%})$ & $13(27.1 \%)$ \\
\hline
\end{tabular}

The results show that the participants mostly expressed negative attitudes towards the use of the aforementioned reproduction-aiding techniques. Less than a fifth of the participants (less than ten) declared that they would agree to using donated eggs or surrogate motherhood. The largest number of negative responses were given in relation to using sperm donation for conception purposes; only two out of 50 participants included in the sample responded that they would agree to in vitro fertilization coupled with donor sperm. The data obtained also indicate that the participants relatively frequently chose the undecided option, with the percentage ranging from $27.1 \%$ to $40 \%$, depending on the 
reproduction-aiding technique, which points to the absence of a firm stance on their use.

Graph 1 features the frequency of the three response categories chosen by participants with different levels of education, reflecting their attitudes towards using donated eggs, donated sperm and surrogacy in their own infertility treatments.

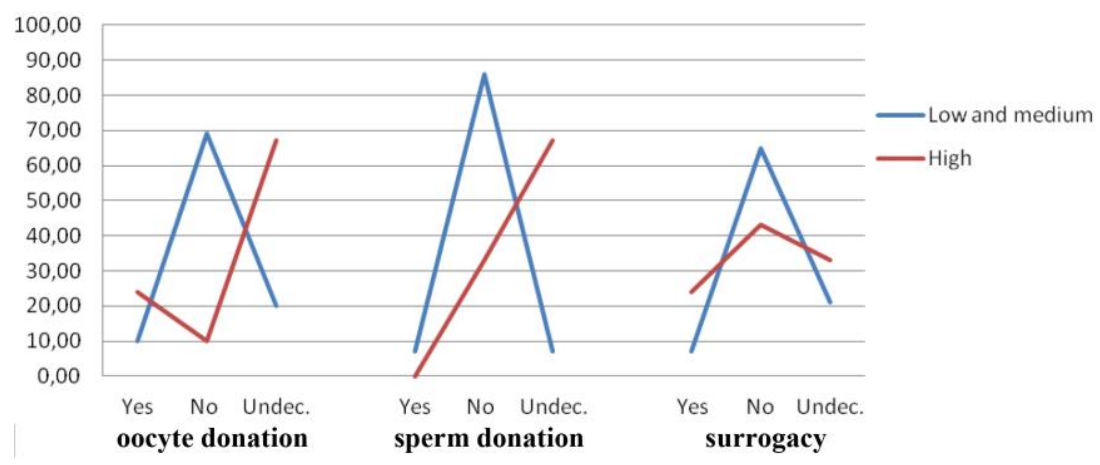

Figure 1 Attitudes towards using donated eggs, donated sperm and surrogacy among participants with different levels of educationthe percentages of the answers "yes", "no" and "undecided"

The data presented in the graph suggests that there are noticeable differences in responses given by participants with different levels of education.

Most of the participants with low- and medium-level education declared that they would not agree to using donated eggs in their own infertility treatments. On the other hand, the most frequent answer among the participants with high-level education was undecided. Spirman's Rho correlation coefficient between level of education and attitude toward using donated eggs was .284 , significant at $\mathrm{p}<.05$ level.

The participants with low- and medium-level education mostly declared that they would not agree to the use of donated sperm as a part of their infertility treatment. Participants with high level of education most frequently chose the option undecided. It is interesting to note that none of the participants with high-level education responded affirmatively when asked whether they would agree to the use of donated sperm in their own infertility treatments. Spirman's Rho correlation coefficient between level of education and attitude toward using donated sperm was high as .632, significant at $\mathrm{p}<.01$ level.

The participants with low- and medium-level education mostly declared that they would not consider surrogacy as a part of their own infertility treatment, while the participants with higher-level education gave fewer negative responses. Spirman's Rho correlation coefficient 
between level of education and attitude toward surrogacy was not statistically significant, indicating that differences between participants with low- and medium-level education on surrogacy may not be statistically significant.

\section{DISCUSSION}

The research presented in this paper was conducted in order to explore the attitudes of infertile women involved in the program of in vitro fertilization towards third-party reproduction, i.e. gamete donation and surrogacy as potential parts of their own infertility treatments. The topic of this research is particularly relevant, due to the fact that infertility has become increasingly "medicalized" by the immense progress in infertility treatments (Fisher, 2001), which has further led to infertility being viewed as a temporary and passing state, while the individuals undergoing infertility treatments tend to see themselves as "not yet pregnant" (Greil, 2002). Above all, the results of the research show that the participants predominantly expressed negative attitudes towards using donated gametes and surrogacy in their own infertility treatments. This is especially the case when it comes to using donated sperm, while negative attitudes were least commonly expressed in relation to the use of donated eggs for the purpose of fertilization. However, a large number of participants were indecisive when asked about their attitudes towards using donated eggs in their own infertility treatments (40\%).

In comparison to the results of other studies on this subject, the attitudes of our subjects were similar or more negative. A research in Turkey surveyed 368 women who had applied for infertility treatments. The results showed that $23 \%$ of the patients would accept donated oocytes, $3 \%$ would accept donated sperm and 15\% would accept gestational surrogacy (Baykal, Korkmaz, Ceyhan, Goktolga, \& Baser, 2008). The results obtained in this research resemble the results of our study; the percentages of positive attitudes towards using donated sperm and surrogacy are identical, while their participants expressed slightly more positive attitudes towards using donated eggs in infertility treatments (23\% in Turkey, in comparison to $16 \%$ in our research).

In a Canadian study which focused the use of reproduction-aiding techniques and involved 2000 childless women (Daniluk \& Koert, 2012), $35 \%$ of the participants stated that they would use donated sperm (in comparison to $4 \%$ of our sample), $25 \%$ would use donated eggs (16\% of our sample) and $26,5 \%$ would opt for surrogate motherhood $(14,5 \%$ of our sample). This study involved female participants from the general population, aged 20 to 50, while our sample involved women battling with infertility. Therefore, the more negative attitudes of the women in our sample are even more surprising. However, one should bear in mind that, in the Canadian research, the "undecided" option was not available. 
More positive attitudes were obtained in another Canadian research (Genuis, Chang, \& Genuis, 1993). In the research in question, 75\% of the participants believed that surrogacy is an acceptable option, provided there are medical reasons for its use, while $15 \%$ of the participants found it acceptable even when there are no medical reasons for such choice. However, this study explored general attitudes towards surrogacy.

The results of a research conducted in Germany (Stobel-Richter, Goldschmidt, Brahler, Weidner, \& Beutel, 2009) show that surrogacy as means of treating infertility was an acceptable option for $44 \%$ of the participants from the general population. The research employed the interview method and the sample comprised 2110 participants, aged 18 to 50 .

A research conducted in Sweden (Skoog-Svanberg, Lampic, Bergh, $\&$ Lundkvist, 2005) revealed that $75 \%$ of the participants considered using donated eggs to be an acceptable way for a couple battling with infertility to have a child. The research was conducted using the questionnaire method, involved participants from the general population (1000 women and 1000 men) and it explored the general attitude towards the method. A research conducted in Turkey, involving 400 participants from the general population, showed that more than half of the participants would rather choose using a donated egg as a part of their infertility treatment, than opt for adoption (Isikoglu et al., 2006).

It is probable that the results of general population surveys do not reflect the real attitudes; that is, that the attitudes are different when the participants are asked whether they themselves would use certain reproduction-aiding techniques in order to solve their own existing problem with infertility. Canadian authors reported that the desire to reproduce was only modestly correlated with the women's (0.248) and men's (0.286) willingness to use AHR options (Daniluk \& Koert, 2012).

It should be noted that this study does have some limitations. Firstly, due to the small sample size, results should be interpreted with caution. Secondly, the study focuses only on "reproductively challenged" women, and not "reproductively challenged" men. Therefore, the fruitfulness of future research may lie in researching intra-gender differences in attitudes towards the use of reproduction-aiding techniques, especially the ones that involve third-party reproduction. Additionally, a comparative analysis of the attitudes of women with vs. women without a biomedical barrier to fertility towards the use of reproduction-aiding techniques would be very useful in exploring gender attitudes towards these techniques. Some studies used this line of inquiry (Johnson \& Simon, 2012). Finally, it is important to bear in mind that different women may view pregnancy differently, that they may or may not have been pregnant before and that they may ascribe different degrees of importance to motherhood itself.

Despite its limitations, this research has made an initial step towards the understanding of the reception of reproduction-aiding techniques which 
involve third-party reproduction among infertile women involved in the in vitro program in Serbia. Additionally, the topic of the research is highly relevant, having in mind the trend of delaying having children and the declining fertility rates in Serbia, which are problems that are being addressed by the current Strategy for Increasing Birth Rate in the Republic of Serbia.

\section{CONCLUSION}

The results of the research show that the participants predominantly expressed negative attitudes towards using donated gametes and surrogacy in their own infertility treatments. In comparison to the results of other studies on this subject, the attitudes of our subjects were similar or more negative.

The results of the research show that negative attitudes towards using third-party gamete donation as parts of infertility treatments were most prevalent among participants with low- and medium-level education. The participants were most uncertain about using donated eggs and donated sperm in their infertility treatments. Expressions of indecisiveness in relation to using the aforementioned reproduction-aiding techniques were most frequent among the subjects with high-level education. It is possible to assume that negative attitudes and the indecisiveness of infertile women in Serbia towards the use of third-party reproduction are the consequences of insufficient information about these reproductive-assisting techniques. However, it is necessary to point out that there was no variable "knowledge" in the research, implying that we should be especially careful when interpreting the results this way.

More importantly, the values and beliefs that contextualize reproduction in a particular society may be strong predictors of attitudes towards the use of certain reproduction-aiding techniques. This paper points to the transition of value forms in Serbia in the domain of family, partnership/marriage and parenting, which we consider to be highly indicative of the interpretation of the presented research results on the attitudes of infertile women towards the use of third-party reproduction. The mentioned polarization of family values on traditional and modern can be interpreted as important sociocultural predictor of negative and ambivalent attitude towards the use of third-party reproduction in Serbia. In the context of the findings reported by Milic (2001), who analyzes the family value system on three (often discordant) levels, it is possible to assume that third-party reproduction leads to the formulation of new (modern) values on the individual (and group) level, while at the same time, the traditional family value system in terms of family form, functions, appropriate way of reproduction and marriage as a basis for procreation persists on the global level. 
Future research on this subject should build on the aforementioned aspects of reproductive decision-making on the part of infertile women.

\section{REFERENCES}

Anleu, S.L.R. (1992). Surrogacy: For love but not for money? Gender and Society, 6(1), 30-48. doi: 10.1177/089124392006001003

Baykal, B., Korkmaz, C., Ceyhan, S.T., Goktolga, U., \& Baser, I. (2008). Opinions of infertile Turkish women on gamete donation and gestational surrogacy. Fertility and Sterility, 89(4), 817-822. doi: 10.1016/j.fertnstert.2007.04.022 pmid: 18406837

Beeson, D., Darnovsky, M., \& Lippman, A. (2015). What's in a name? Variations in terminology of third-party reproduction. Reproductive BioMedicine Online 31(6), 805-814. doi: 10.1016/j.rbmo.2015.09.004 pmid: 26526414

Bilinović, A. (2016). Uticaj asistirane reprodukcije na redefinisanje socioloških pojmova porodice $i$ roditeljstva [The effect of assisted reproduction on redefining the sociological notions of family and parenthood]. (Doktorska disertacija) http://nardus.mpn.gov.rs/bitstream/handle/123456789/6542/ Disertacija4519.pdf?sequence $=1$

Blagojević, M. (2007). Promene vrednosti i rodni režimi u zemljama u tranziciji komparativna perspektiva. U: N. Petrušić, (ur.), Putevi ostvarivanja rodne ravnopravnosti i jednakih mogućnosti - Od ideje do prakse [Roads to achieve gender equality and equal opportunities - From idea to practice]. (str. 87-98). Beograd: Savet za ravnopravnost polova Vlade RS.

Bobić, M. (2003). Brak i/ili partnerstvo [Marriage and/or partnership]. Beograd: Čigoja štampa.

Corea, G. (2005). The subversive sperm: A false strain of blood. In: R. T. Hull (Ed.). Ethical Issues in the New Reproductive Technologies, Second edition. New York: Prometheus Books, (63-76).

Daniluk, J.C. \& Koert, E. (2012). Childless Canadian men's and women's childbearing intentions, attitudes towards and willingness to use assisted human reproduction. Human Reproduction, 27(8), 2405-2412. doi: 10.1093/humrep/ des190 pmid: 22684907

Daniluk, J.C., Koert, E., \& Cheung, A. (2012). Childless women's knowledge of fertility and assisted human reproduction: Identifying the gaps. Fertility and Sterility, 97(2), 420-426. doi: 10.1016/j.fertnstert.2011.11.046 pmid: 22192349

Drezgić, R. (2008). Od planiranja porodice do populacione politike - promene vladajuće paradigme u srpskoj demografiji krajem 20. veka [From family planning to population policy - changes in the ruling paradigm in Serbian demography at the end of the 20th century]. Filozofija i društvo, 19 (3), 181-215.

Drezgić, R. (2010). „Bela kuga” među „Srbima”: o naciji, rodu i rađanju na prelazu vekova "White plague" among "Serbs": about nation, gender and birth at the passage of centuries]. Beograd: Albatros plus, Institut za filozofiju i društvenu teoriju.

Fisher, A.P. (2001). Still "not guite as good as having your own"? Toward a sociology of abortion. Annual Review of Sociology, 29(1), 335-361. doi: 10.1146/annurev.soc.29.010202.100209

Genuis, S.J., Chang, W.C., \& Genuis, S.K. (1993). Public attitudes in Edmonton toward assisted reproductive technology. Canadian Medical Association Journal, 149(2), 153-161. pmid: 8324713 
Greil, A.L. (2002). Infertile bodies: Medicalization, metaphor, and agency. In: M.C. Inhorn \& F. van Balen (Eds.). Infertility around the Globe: New Thinking on Childlessness, Gender, and Reproductive Technologies. Berkeley: University of California Press, (101-118).

Ikemoto, L. I. (2009). Eggs as capital: Human egg procurement in the fertility industry and the stem cell research enterprise. Signs, 34(4), 763-781. doi: $10.1086 / 597131$

Isikoglu, M., Senol, Y., Berkkanoglu, M., Ozgur, K., Donmez, L., \& Stones-Abbasi, A. (2006). Public opinion regarding oocyte donation in Turkey: First data from a secular population among the Islamic world. Human Reproduction, 21(1), 318-323. doi: 10.1093/humrep/dei274 pmid: 16123084

Jackson, E. (2001). Regulating Reproduction: Law, Technology and Autonomy. Oxford: Hart Publishing.

Johnson, K.M. \& Simon, R.M. (2012). Women's attitudes toward biomedical technology for infertility. Gender and Society, 26(2), 261-289. doi: 10.1177/ 0891243211434615

Krawiec, K.D. (2009). Sunny Samaritans and egomaniacs: Price-fixing in the gamete market. Law and Contemporary Problems, 72(3), 59-90.

Kričković Pele, K. (2014). Vantelesna oplodnja: rodne i društvene kontroverze [In vitro fertilisation: gender and social controversy]. Novi Sad: Zavod za ravnopravnost polova i ACIMSI Centar za rodne studije Univerziteta u Novom Sadu.

Kupka, M.S., D’Hooghe, T., Ferraretti, A.P., de Mouzon, J., Erb, K., Castilla, J.A., CalhazJorge, C., De Geyter, C., \& Goossens, V. (2016). Assisted reproductive technology in Europe: Results generated from European registers by ESHRE. Human Reproduction, 31(2), 233-248. doi: 10.1093/humrep/dev319

Manić, I. (2016). Porodične vrednosti mladih u Srbiji [Family values of young people in Serbia]. Sinteza, 9, 1-14.

McLachlan, H.V. \& Swales, J.K. (2009). Commercial surrogate motherhood and the alleged commodification of children: A defense of legally enforceable contracts. Law and Contemporary Problems, 72(3), 91-107.

Milić, A. (2001). Sociologija porodice - kritika i izazovi [Sociology of the family critique and challenges]. Beograd: Čigoja štampa.

Milić, A. (2010). Porodične vrednosne orijentacije - vrednosni raskol. U Vreme porodica [The time of family] (str. 235-256). Beograd: Čigoja štampa; Beograd: Institut za sociološka istraživanja Filozofskog fakulteta.

Poulton, J. \& Oakeshott, P. (2012). Preventing maternal transmission of mitochondrial DNA disease: Nuclear transfer would be a major advance, but safe alternatives exist for most affected families. British Medical Journal, 345(7877), 10.

Robertson, J.A. (1994). Children of Choice: Freedom and the New Reproductive Technologies. New Jersey: Princeton University Press.

Sandelowski, M. \& de Lacey, S. (2002). The uses of a 'disease': Infertility as rhetorical vehicle. In: M.C. Inhorn \& F. van Balen (Eds.). Infertility around the Globe: New Thinking on Childlessness, Gender, and Reproductive Technologies. Berkeley: University of California Press, (33-51).

Shanley, M.L. (2002). Collaboration and commodification in assisted procreation: Reflections on an open market and anonymous donation in human sperm and eggs. Law and Society Review, 36(2), 257-284. doi: 10.2307/1512177

Skoog-Svanberg, A., Lampic, C., Bergh, T., \& Lundkvist, O. (2003). Public opinion regarding oocyte donation in Sweden. Human Reproduction,18(5), 11071114. doi: 10.1093/humrep/deg222 pmid: 12721192

Službeni glasnik RS (2009a). Pravilnik o jedinstvenom registru donora reproduktivnih ćelija. [Official Gazette of the Republic of Serbia. The Act on Treating 
Infertility via Biomedically Assisted Fertilization], Volume 72. Retrieved 30 July 2016 (Available from:

http://www.paragraf.rs/propisi/zakon_o_lecenju_neplodnosti_postupcima_biomedicin ski_potpomognutog_oplodjenja.html).

Službeni glasnik RS (2009b). Zakon o lečenju neplodnosti postupcima biomedicinski potpomognutog oplođenja. [Official Gazette of the Republic of Serbia. Rulebook on the Unique Register of Reproductive Cell Donors], Volume 85. Retrieved 30 July 2016 (Available from: http://www.podaci.net/ gSRB/propis/Pravilnik_o_Jedinstvenom/P-jrdrce03v1385.html).

Stobel-Richter, Y., Goldschmidt, S., Brahler, E., Weidner, K., \& Beutel, M. (2009). Egg donation, surrogate mothering, and cloning: attitudes of men and women in Germany based on a representative survey. Fertility and Sterility, 92(1), 124-130. doi: 10.1016/j.fertnstert.2008.05.015 pmid: 18684445

Twine, F.W. (2011). Outsourcing the Womb: Race, Class, and Gestational Surrogacy in a Global Market. New York: Routledge. doi: 10.4324/9780203834206

van Balen, F. \& Inhorn, M.C. (2002). Interpreting infertility: A view from the social sciences. In: M.C. Inhorn \& F. van Balen (Eds.). Infertility around the Globe: New Thinking on Childlessness, Gender, and Reproductive Technologies. Berkeley: University of California Press, (3-32).

Гавриловић, Д. \& Стјепановић-Захаријевски, Д. (2012). Традиционалне и модерне вредности у транзиционој Србији [Traditional and modern values in transitional Serbia]. Теме, 36 (3), 1087-1102.

Захаријевски, Д. С. (2009). Полне/родне разлике у конституисању идентитета и породичних вредносних образаца [Sex/gender differences in the constitution of identity and family value patterns]. Годишъак за соииологију, 5(5), 143-154.

\title{
СТАВОВИ НЕПЛОДНИХ ЖЕНА У СРБИЈИ ПРЕМА КОЛАБОРАТИВНОЈ РЕПРОДУКЦИЈИ
}

\author{
Ана Билиновић Рајачић ${ }^{1}$, Марија Зотовић ${ }^{2}$, \\ Марко Шкорић ${ }^{1}$, Ксенија Кричковић Пеле \\ ${ }^{1}$ Универзитет у Новом Саду, Филозофски факултет, Департман за социологију, \\ Нови Сад, Србија \\ ${ }^{2}$ Универзитет у Новом Саду, Филозофски факултет, Департман за социологију, \\ Нови Сад, Србија \\ ${ }^{3}$ Универзитет у Новом Саду, Медицински факултет, Клинички центар \\ Војводине, Клиника за гинекологију и акушерство, Нови Сад, Србија
}

\section{Резиме}

Као одговор на проблеме у вези са неплодношћу, широм света се улажу значајни напори у развој и унапређивање употребе асистираних репродуктивних технологија. Највеће контроверзе изазива употреба техника које подразумевају учешће треће особе у репродукцији, а за које се користи заједнички назив „колаборативна репродукција”. Колаборативна репродукција је термин који се односи на употребу гамета или ембриона, као и на гестацију коју обезбеђује трећа особа како би неплодна индивидуа или неплодни пар могли да постану родитељи. Друштвена, правна и етичка прихватљивост колаборативне репродукције разликује се у различитим деловима света. Имајући у виду недостатак истраживања о употреби 
донираних гамета у Србији, као и забрану сурогат материнства у Србији (иако се некомерцијално сурогат материнство дозвољава нацртом грађанског законика који би требало да буде усвојен до краја 2018. године), истражили смо ставове жена које се лече од неплодности према колаборативној репродукцији. Прецизније, циљ истраживања је испитивање ставова неплодних жена у Србији према донирању гамета и сурогат материнству као методама лечења властите неплодности.

Узорак је укључивао 50 неплодних жена, које су укључене у процес „іn vitro” оплодње, што чини минимум 10 \% од укупног броја жена које пролазе кроз програм финансиран од стране државе на клиници у Новом Саду. Испитанице су попуњавале упитник сачињен за потребе истраживања. Пре свега, резултати указују на то да највећи број испитаница има негативне ставове према оплодњи путем донираних гамета и сурогат материнству као методама лечења неплодности. Негативни ставови посебно су изражени када је у питању коришћење дониране сперме, док су најмање присутни када је у питању коришћење дониране јајне ћелије у сврху зачећа. Међутим, велики број испитаница остао је неодлучан у свом ставу према техникама колаборативне репродукције, посебно када је у питању коришћење дониране јајне ћелије. Поредећи добијене податке са резултатима других истраживања на ову тему, могуће је уочити да су ставови наших испитаница слични ставовима (неплодних) жена у другим земљама или су нешто негативнији. Резултати показују да су негативни ставови најзаступљенији код испитаница са нижим и средњим нивоом образовања. Велики број испитаница неодлучан је када је у питању коришћење дониране јајне ћелије и сперме у оквиру сопственог третмана неплодности. Неодлучне испитанице најчешће су у категорији са вишим образовањем.

Упркос ограничењима које има, ово истраживање представља први корак ка разумевању односа према методама колаборативне репродукције код жена које су укључене у програм „іn vitro” оплодње у Србији. Тема истраживања је високо релевантна, имајући у виду тренд одлагања родитељства и повећан број случајева стерилитета, што су проблеми који су узети у обзир и приликом израде актуелне Стратегије за подстицање рађања у Републици Србији. 